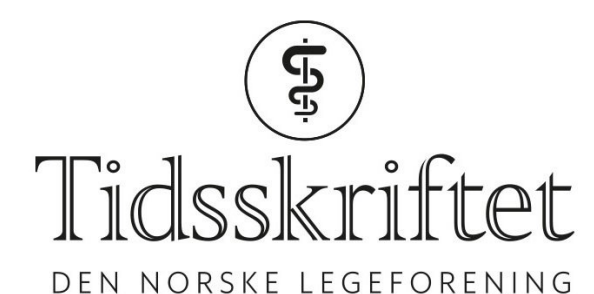

DEN NORSKE LEGEFORENING

\title{
Grundig om kommunikasjon og sykepleie
}

ANMELDELSER

TOR ANVIK

Førsteamanuensis og tidligere spesialist i allmennmedisin, Institutt for samfunnsmedisin Universitetet i Troms $\emptyset$ - Norges arktiske universitet

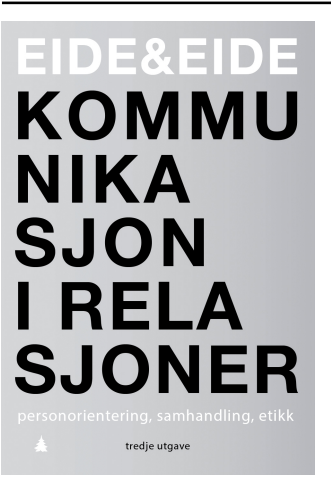

Hilde Eide, Tom Eide

Kommunikasjon i relasjoner

Personorientering, samhandling, etikk. 3.utg. 420 s, tab, ill. Oslo: Gyldendal Akademisk, 2017. Pris NOK 599

ISBN 978-82-05-50056-3

Dette er tredje reviderte utgave av en akademisk fagbok først og fremst beregnet på sykepleiere. Begge forfatterne er professorer ved Høgskolen i Sørøst-Norge og har mange års erfaring fra undervisning og forskning om kommunikasjon, etikk og ledelse innenfor helsefag.

Boken er inndelt i fire deler med til sammen 14 kapitler. Hvert kapittel åpner med en boks med overskriften «Når du har lest dette kapitlet har du kunnskap om», etterfulgt av 5-7 punkter med læringsmål. Innholdet illustreres med en rekke eksempler på situasjoner og samtaler mellom sykepleiere og pasienter, pårørende eller studenter. De fleste eksemplene er hentet fra sykehus eller sykehjem.

De første kapitlene omhandler grunnelementene i personorientert kommunikasjon, mestring innen kommunikasjon (blant annet med en tilnærming og unngåelses-modell) og relasjonsetikk etter Løgstrup og Levinas. Her finnes også en syvtrinns modell for etisk refleksjon. I de neste kapitlene gjennomgår forfatterne konkrete kommunikasjonsferdigheter som aktiv lytting, verbal og ikke-verbal kommunikasjon, 
empati og utforskende, informerende og utfordrende ferdigheter. I flere kapitler beskrives motiverende samtaler ved behov for livsstilsendringer samt kommunikasjon med henholdsvis barn, eldre og grupper.

Dette er en tung ( $750 \mathrm{~g}$ ), tykk ( $25 \mathrm{~mm}$ ), omfangsrik (432 sider) og forskningsbasert (mer enn 350 litteraturhenvisninger) bok. Selv om målgruppen først og fremst er sykepleiere, mener jeg at den er av interesse for leger og andre helseprofesjoner. Mange av kapitlene om konkrete kommunikasjonsferdigheter inneholder beskrivelser av teorigrunnlag og praktiske ferdigheter som er felles for mange helseprofesjoner. I kapitlet om endringsveiledning omtales både teori og ferdigheter i kommunikasjon på en måte som også er relevant i medisinstudiet. Slike kapitler kan med hell leses enkeltvis, slik forfatterne anbefaler. Boken gir gode eksempler på kommunikasjon i veiledningssamtaler mellom lærer og student, og det er teori og praktiske råd om gruppeledelse og konflikthåndtering som er aktuelle i mange sammenhenger. Det siste kapitlet gir noen gløtt inn i det teoretiske og filosofiske grunnlaget for sykepleievitenskapen. Disse kan også være av interesse for personer med annen faglig bakgrunn.

Layouten og stikkordslisten er god og teksten lettlest med moderat bruk av fremmedord.

Publisert: 19. februar 2018. Tidsskr Nor Legeforen. DOI: 10.4045/tidsskr.17.0996

(C) Tidsskrift for Den norske legeforening 2020. Lastet ned fra tidsskriftet.no 